Криштопа С.І., Криштопа Л.І., Микитій I.М., Гнип М.М., Козак Ф.В.

Івано-Франківській національний технічний університет нафти і газу

\title{
ПОКРАЩЕННЯ ЕКОЛОГІЧНИХ ПАРАМЕТРІВ ДИЗЕЛЬНИХ ДВИГУНІВ ПРИ ЇХНЬОМУ ПЕРЕВЕДЕННЯ НА ПРОДУКТИ КОНВЕРСІЇ МЕТАНОЛУ
}

\begin{abstract}
Стаття спрямована на вирішення проблеми конвертації існуючих автомобільних дизельних двигунів на газові палива, які $є$ більш дешевою та екологічною альтернативою дизельного палива. Був удосконалений метод підвищення енергії альтернативних палив. Розглянута хімічна сутність підвищення енергії палива на основі наукових положень термодинаміки. В якості вихідного продукту для конверсійного процесу здійснено вибір альтернативного метанольного палива, що враховує його собівартість, екологічність та температурні умови. Проведені розрахунки показали, що тепловий ефект від спалювання конвертованій суміші перевищує ефект від спалювання тієї ж кількості неконвертованого метанолу. Енергія палива підвищувалась за рахунок термохімічної регенерації теплоти відпрацьованих газів. Створена експериментальна установка для дослідження роботи переробленого дизельного двигуна на продуктах конверсії метанолу. Проведені експериментальні дослідження екологічних показників дизельного двигуна, який був переобладнаний на роботу на продуктах конверсії метанолу. Виконані експериментальні дослідження показали, що переведення дизельних двигунів на роботу 3 використанням продуктів конверсії метанолу $\epsilon$ технічно обгрунтованим. Зниження витрати палива супроводжувалося поліпшенням екологічних якостей дизеля, що працює спільно 3 термохімічним реактором конверсії метанолу. У залежності від частоти обертання колінчастого валу та навантаження на двигун утворення оксидів азоту у відпрацьованих газах знижувалося на 53-60 \%, оксиду вуглецю відбувалось в межах 52-62 \%. 3 врахуванням того, що ціна метанолу складає до $20 \%$ від вартості дизельного палива, переведення автомобільних дизельних двигунів на роботу 3 використанням продуктів конверсії метанолу $є$ дуже вигідним.

Ключові слова: дизельний двигун; альтернативне паливо; метиловий спирт; утилізація теплоти; відпрацьовані гази; оксиди азоту; вуглеводні.
\end{abstract}

\section{ВСТУП}

Велика частка автомобільного та інших видів транспорту використовує дизельні двигуни. Це вимагає при роботі двигунів великих витрат дорогого дизельного палива 3 досить істотними показниками токсичності відпрацьованих газів, тому очевидною $\epsilon$ доцільність переходу на більш екологічні види альтернативних палив [1]. Дизельні двигуни мають великий ресурс $\mathrm{i}$ поза сумнівом навіть після повного припинення випуску нових дизельних двигунів, вже випущені дизельні двигуни ще довгий час будуть знаходитись в експлуатації. Тому на особливу увагу заслуговує проблема переведення існуючих дизельних силових приводів на газові палива, які $\epsilon$ більш дешевою та екологічною альтернативою дизельного палива.

\section{АНАЛІЗ ЛІТЕРАТУРНИХ ДАНИХ ТА ПОСТАНОВКА ПРОБЛЕМИ}

Конвертація дизельних двигунів на газомоторне паливо можлива за різними схемами [2]. В загальному, дизельний двигун можна переобладнати на газодизельний або моногазовий режими (рис. 1). В даний час вже $\epsilon$ добре відомою та достатньо відпрацьованою технологія переведення дизельних двигунів на газодизельний режим, коли

одночасно використовується подача як газу, так i дизпалива. В цьому випадку до газового палива подається запальна доза дизельного палива, яка виробниками газодизельних систем позиціонується в межах $25-40 \%$, а в реальних умовах експлуатації досягає і 50 \%. Ця технологія разом з певними перевагами має і багато недоліків [3], один 3 головних - залишається необхідність подачі дизельного палива, що погіршує економічну доцільність переобладнання. 


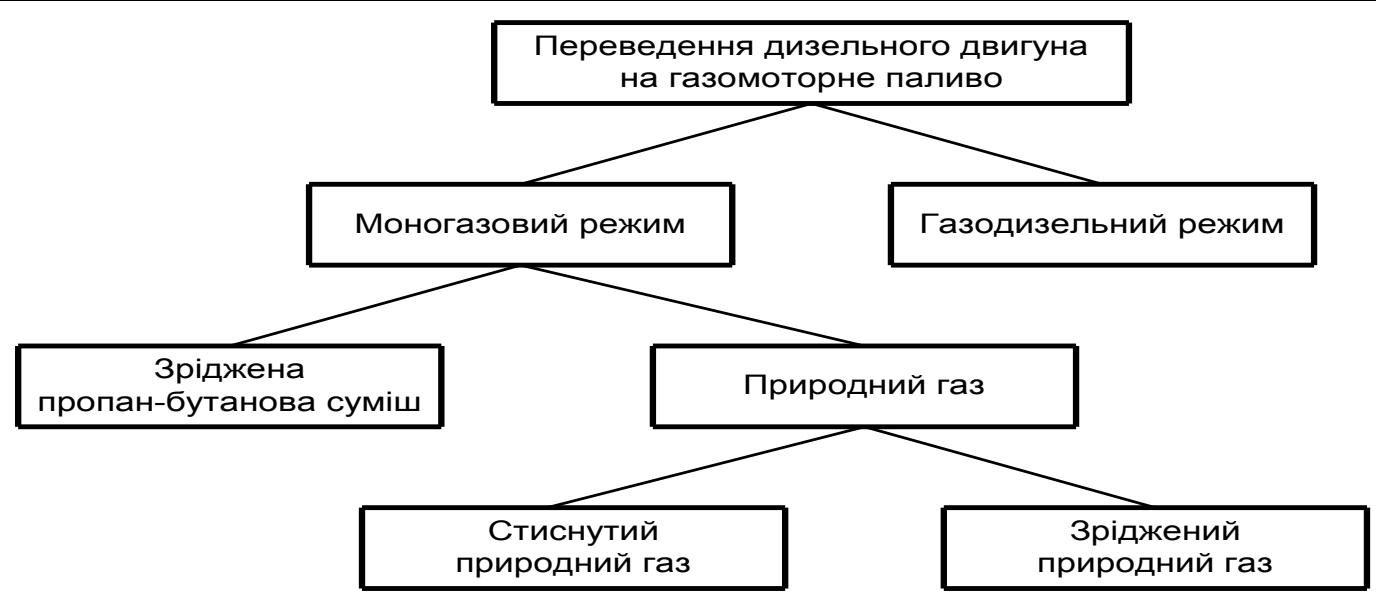

Рисунок 1 - Напрямки конвертації дизельних двигунів на газ

Другий, поки що менш апробований варіант конвертації дизельних двигунів на газомоторне паливо - це чисто газовий або моногазовий режим, де конвертовані дизельні двигуни додатково обладнуються системами 3 іскровим запалюванням. Очевидно, що подавання тільки чистого газу або моногазовий режим $є$ більш вигідною альтернативою газодизельного режиму 3 врахуванням відсутності необхідності подачі дорогого дизельного палива. Дизельний двигун за своєю конструкцією може бути переобладнаний для роботи 3 газобалонним обладнанням як на метані (на стиснутий або зріджений), так і на пропан-бутані [4].

Вивчення досвіду зарубіжних $\mathrm{i}$ вітчизняних розробок свідчить, що дизельні двигуни, які конвертовані в газові, мають високі тягово-динамічні та економічні характеристики, а за показниками екологічної безпеки істотно перевершують базові дизельні двигуни [5].

Конвертація дизельного двигуна в моногазовий, на відміну від переобладнання бензинових двигунів, вимагає серйозних змін в конструкції базового дизеля [8]. Оскільки дизельний двигун $\epsilon$ двигуном, займання палива в якому здійснюється при нагріванні від стиснення, то стандартний дизельний двигун не може працювати на газовому паливі, так як газомоторне паливо має істотно більш високу температуру займання у порівнянні 3 дизельним паливом (наприклад, дизпаливо - 300-330 ${ }^{0} \mathrm{C}$, пропан - $466{ }^{0} \mathrm{C}$ ), яка не може бути досягнута при ступенях стиску, що використовуються в дизельних двигунах.

Другою причиною, за якою дизельний двигун не зможе працювати на газовому паливі $\epsilon$ явище детонації - це вибухоподібне горіння палива, яке виникає при високій степені стиснення. Для дизельних двигунів використовуються ступінь стиснення паливоповітряної суміші від 14 до 22, а газовий двигун повинен мати ступінь стиску до від

12 до 13 [7]. Необхідно відмітити, що зменшення степені стиску у переобладнаних дизельних двигунах, що переобладнувались в газові, виконується, як правило, за рахунок розточування камери згоряння в поршні базового дизеля. Однак експериментальні дослідження показують, що навіть незначні зміни форми камер згоряння в поршнях призводять до значних змін у процесах теплогазомасообміну та згорання [8]. Тому оптимізація камери згоряння конвертованого двигуна потребує серйозних розрахункових $\mathrm{i}$ експериментальних робіт для забезпечення високих потужнісних, економічних та екологічних показників двигуна.

Для конвертації дизельних двигунів на газове паливо, в загальному, необхідно виконати наступне: встановити газобалонну апаратуру; зменшити ступінь стиснення базового дизельного двигуна; змонтувати систему запалення; виконати настройку системи

управління двигуном. Необхідно зазначити, що поки набутий початковий досвід в напрямку конвертації дизельних двигунів в моногазові $\mathrm{i}$ для вирішення питання доцільності переобладнання дизельних двигунів в газові потрібно дати відповіді на багато питань науково-технічного та комерційного характеру [9]. 
При виборі виду газового палива необхідно обов'язково враховувати перетворення хімічної енергії палива в роботу. Перетворення хімічної енергії будь-якого виду палива в роботу в двигунах внутрішнього згоряння здійснюється в два етапи: на першому вона перетворюється в теплоту, на другому етапі теплота реалізується в роботу. При цих перетвореннях і відбуваються основні втрати енергії палива, що можуть суттєво підвищувати показники ефективності роботи двигуна внутрішнього згоряння [10]. Для підвищення ефективності використання хімічної енергії палива в двигунах внутрішнього згоряння необхідно знизити іiі втрати на обох етапах перетворення. До теперішнього часу в двигунобудуванні, в основному, застосовуються способи зменшення втрат енергоефективності палива на другому етапі перетворення енергії.

У сучасних двигунах температурний рівень робочого тіла такий, що його подальше підвищення обумовлює серйозну проблему забезпечення необхідної термічної міцності [11]. Тому підвищення ефективності використання палива в тепловому двигуні шляхом підвищення верхньої термодинамічної температури робочого тіла в циклі залежить від можливостей подальшого підвищення жаростійкості i жароміцності конструкційних матеріалів деталей двигуна. Якщо врахувати, що ці можливості для більшості традиційних матеріалів вже практично вичерпані, стає очевидним, що такий спосіб стає малоперспективним. У цих умовах доцільна розробка способу зниження необоротних втрат на першому етапі перетворення хімічної енергії палива в теплоту. Причому, реалізація цього способу по можливості не повинна бути пов'язана 3 підвищенням температурного рівня робочого тіла. Стосовно до двигунів внутрішнього згоряння для забезпечення попереднього ендотермічного етапу конверсії в якості вихідного конвертованого продукту доцільно використовувати такі види альтернативних палив, які мають температуру конверсії нижче середнього температурного рівня відпрацьованих газів [12]. До таких палив можуть відноситись нижчі спирти, алкани і прості ефіри. Вибір альтернативного палива в якості вихідного продукту для конверсійного процесу $\epsilon$ компромісом, що враховує температурні умови процесу, його енергетичну цінність, утворені при переробці гази і їхню собівартість.

До найбільш перспективному вихідного продукту для організації конверсії в першу чергу слід віднести метиловий спирт (метанол), який у світовій практиці вже давно застосовується в якості дешевого замінника дорогих традиційних моторних палив. Для порівняння середня вартість палив в Європі коливається в межах [13]: дизельного палива - 1,15-1,9 євро/кг (1-1,6 євро/літр); метану - 0,05-0,1 євро/кг; октану - 0,55-0,8 євро/кг; пропану - 0,4-0,75 євро/кг; етанолу - 0,2-0,3 євро/кг; метанолу - 0,15-0,25 євро/кг.

В якості альтернативного палива для дизельного двигуна, 3 економічної точки зору, доцільно використовувати метанол [14]. Метанол відноситься до поновлюваних природних ресурсів, тобто існує велика сировинна база для збільшення його виробництва i значно ширшого використання як енергоносія. Метанол широко використовується в хімічній промисловості i чималі його обсяги застосовуються у виробництві палив для автотранспорту. Використання цього спирту в якості альтернативного біопалива для автотранспорту $\epsilon$ можливим в результаті його отримання доступними та дешевими способами 3 сільськогосподарських та харчових відходів, 3 газоподібного палива. Але одна 3 найбільш важливих причин застосування метанолу це зниження викидів токсичних компонентів 3 відпрацьованих газів автомобільного транспорту.

В даний час основним споживачем метанолу $\epsilon$ хімічна промисловість. Метиловий спирт зі своєю більш простою структурою і незначними розмірами молекул $\epsilon$ одним 3 визначальних чинників більш «чистого згоряння» палива [15]. У порівнянні 3 іншими альтернативними паливами вартість метилового спирту невисока, крім того, при використанні метанолу, як палива для дизелів, можна значно знизити викиди часток сажі та оксидів азоту. Це відбувається внаслідок того, що при горінні метанолу в циліндрі дизеля не утворюються проміжні продукти, що сприяють зародженню ацетиленових i ароматичних вуглеводнів, які і призводять до утворення сажі [16].

Метанол має високе октанове число i низький рівень пожежонебезпеки. Він погано розчиняється в нафтових паливах. Температура відпрацьованих газів двигунів при 
роботі на метанольній суміші на $30-70{ }^{\circ} \mathrm{C}$ нижче в порівнянні 3 базовими двигунами внутрішнього згоряння [17]. Застосування зрідженого метанолу в якості палива супроводжується підвищеним зносом циліндро-поршневої групи, викликаним попаданням його крапель на стінки циліндра i руйнуванням плівки масла.

\section{ЦІЛЬ ТА ЗАДАЧІ ДОСЛІДЖЕННЯ}

Ціль роботи - підвищення енергоефективності альтернативних палив для автомобільних та тракторних дизельних двигунів шляхом використання енергоефективної системи конвертації метанолу 3 дослідженням екологічних параметрів дизельних двигунів при їхньому переведення на продукти конверсії метанолу.

Для вирішення вказаної цілі виносяться такі задачі:

-теоретично дослідити можливість підвищення енергоефективності альтернативних палив шляхом розроблення системи конвертації метанолу та використання теплоти відпрацьованих газів;

-дослідити експериментально зміну складу продуктів згоряння при переобладнання дизельного двигуна на роботу на продукти конверсії метанолу.

\section{РЕЗУЛЬТАТИ ДОСЛІДЖЕНЬ}

\section{Теоретичні основи методу підвищення енергії палива}

Хімічна сутність підвищення енергії вихідного палива відображають основні положення термодинаміки, зокрема, закон Гесса. Покажемо це на основі аналізу теплових ефектів від згоряння метанолу, здійснюваного за двома методами. Відповідно до першого i другого методів окислення метанолу початковий i кінцевий стани системи однакові: початковий - 1 кмоль $\mathrm{CH}_{3} \mathrm{OH}$, кінцевий -2 кмоль $\mathrm{H}_{2} \mathrm{O}$ та 1 кмоль $\mathrm{CO}_{2}$.

За першим методом метанол безпосередньо спалюються в камері згоряння двигуна внутрішнього згоряння

$$
\mathrm{CH}_{3} \mathrm{OH}+3 / 2 \mathrm{O}_{2} \rightarrow 2 \mathrm{H}_{2} \mathrm{O}+\mathrm{CO}_{2}+Q_{M},
$$

де $Q_{M}-$ екзотермічний тепловий ефект від згорання метанольно-повітряної суміші, $Q_{M}=629440$ кДж [3].

В результаті реакції (1) за першим методом утворюються 3 кмоль продуктів згоряння. спирт

За другим двоступінчастим методом конверсії метанолу спочатку розкладається

$$
\mathrm{CH}_{3} \mathrm{OH} \rightarrow 2 \mathrm{H}_{2}+\mathrm{CO}-Q_{c} .
$$

При цьому утворюються 2 кмоль $H_{2}$ та 1 кмоль СО 3 ендотермічною теплотою конверсії $Q_{c}$.

Потім спалюють в кисні 3 кмоль, отриманих в результаті реакції (2) продуктів конверсії метанолу:

$$
\begin{aligned}
& 2 \mathrm{H}_{2}+\mathrm{O}_{2} \rightarrow 2 \mathrm{H}_{2} \mathrm{O}+481500 \kappa Д ж ; \\
& \mathrm{CO}+1 / 2 \mathrm{O}_{2} \rightarrow \mathrm{CO}_{2}+282600 \kappa Д ж .
\end{aligned}
$$

Сумарний тепловий ефект

$$
Q_{\Sigma}=282600+481500=764100 \text { кДж / кмоль }
$$

Теплові ефекти для реакцій (3-4) наведені згідно 3 даними [18]. Тоді у відповідності до закону Гесса сумарні теплові ефекти різних маршрутів окислення метанолу повинні збігатися

629440 кДж / кмоль $=-Q_{c}+764100$ кДж / кмоль.

Звідси ендотермічний тепловий ефект конверсії (реакції дисоціації метанолу) буде складати

$Q_{c}=134660$ кДж / кмоль. 
Отже, проведений розрахунок показав, що тепловий ефект від спалювання конвертованій суміші $\mathrm{CO}$ i $H_{2}$ перевищує ефект від спалювання тісї ж кількості неконвертованого метанолу (вихідне паливо) на $Q_{c}=134660$ кДж / кмоль (тобто на

21,4\%), що відповідає витраченій при розкладанні спирту енергії.

Можна стверджувати, що реалізація такого способу апріорі можлива лише при наявності альтернативних палив, спалювання яких при однаковій температурі супроводжувалося б різними рівнями необоротних втрат. Подібні палива шляхом термохімічних перетворень можна перетворити в нове (штучне) паливо 3 більш високим енергетичним потенціалом. Переведення хімічної енергії такого штучного палива в теплоту супроводжується меншими незворотними втратами. Вказаний спосіб переведення хімічної енергії розроблений на базі фундаментальних положень термохімії i може бути застосований для будь-якого виду енергетичної установки. Запропонований спосіб передбачає необхідність організації ендотермічного процесу конверсії палива, в основі якого лежить цикл його термохімічного перетворення, а в робочому циклі енергоустановки передбачається ще один процес. Якщо в звичайній енергоустановки хімічна енергія палива перетворюється в теплоту в одну стадію, то в запропонованому способі - в дві.

На першій - вихідне паливо піддається конверсії, а на другий - конвертоване паливо спалюється на більш високому енергетичному рівні. Дві стадії перетворення енергії, в процесі яких використовується теплота, що відводиться 3 циклу, дозволяють підвищити ефективність використання енергії вихідного палива. У загальному випадку ефективність термохімічної регенерації залежить від типу енергоустановки, способу i умов організації в ній робочого процесу, а також від виду палива та ендотермічного ефекту системи реакцій його конверсії.

Слід зазначити, що продукти конверсії традиційного нафтового палива, отримані в термохімічної реакторі на основі механізму екзотермічних реакцій неповного окислення вуглеводнів, мають порівняно 3 вихідним паливом нижчу теплоту згоряння, що виключає прояв ефекту регенерації. метанолу.

Проведемо розрахунок підвищення теплоти згорання продуктів конверсії зрідженого

Теплота згоряння газоподібних продуктів конверсії метанолу Hи.n.м = 23870 кДж

/ кг [19]. Теплота згоряння метанолу Ни.м = 19670 кДж / кг (табл. 1).

Таблиця 1 - Порівняльні характеристики теплоти згоряння метанолу та дизельного палива

\begin{tabular}{|c|c|c|c|}
\hline Показник & Дизельне & Метанол & $\begin{array}{c}\text { Конвертований } \\
\text { метанол }\end{array}$ \\
\hline Теплота згоряння абсолютна, кДж/кг & 42500 & 19700 & 23870 \\
\hline Теплота згоряння відносна, \% & 100 & 46,35 & 56,17 \\
\hline
\end{tabular}

Таким чином, при згорянні в двигуні 1 кг продуктів конверсії метанолу, отриманих 3 такою ж маси рідкого метанолу, вивільняється додаткова теплова енергія Ни.к, накопичена в процесі конверсії спиртового палива

$$
\text { Hи.к =Hu.n.м }-H u . м=4200 \text { кДж / кг }
$$

Отже, 21,4 \% енергії вихідного палива повертається в робочий цикл двигунів внутрішнього згоряння для здійснення корисної роботи.

При організації ендотермічної конверсії в умовах реальної експлуатації двигуна внутрішнього згоряння ця енергія одержується на основі утилізації теплової енергії відпрацьованих газів. Згідно зовнішнього теплового балансу двигуна внутрішнього згоряння істотна частина хімічної енергії палива не реалізується у вигляді роботи i відводиться, в тому числі, 3 відпрацьованими газами в навколишній простір. У дизельних двигунах складова енергетичних втрат в тепловому балансі досягає 25-40 \% [20], в бензинових i газових двигунах частка необоротних втрат теплоти, що 
втрачається 3 двигуна 3 відпрацьованими газами, становить 30-45 \%. Це відповідає 13 22 МДж теплоти на 1 кг витраченого палива.

Для забезпечення процесу конверсії теплота має відбиратись від випускного колектора, де температура деталей двигуна досягає від 700-800 К на оборотах холостого ходу до 1100-1200 K на режимах максимальних навантажень. Навіть 3 врахуванням втрат теплоти при передачі енергії від двигуна до робочого тіла, абсолютно безпроблемним $є$ досягнення метанолом температури конверсії в $T_{\kappa}=570$ К.

3 викладеного вище випливає, що застосування систем попереднього хімічного перетворення альтернативного палива дозволяє підвищити ефективність його використання

в двигунах внутрішнього згоряння за рахунок регенерації теплоти відпрацьованих газів.

Теплота, придатна для регенерації в цикл, виражена як частина відхідної теплоти $Q_{B}$, тобто ступінь регенерації дорівнює

$$
\eta_{p}=\frac{Q_{c}}{Q_{b}},
$$

де $Q_{b}-$ кількість теплоти, яка була відведена за цикл.

Кількість теплоти $Q_{b}$, яка була відведена за цикл (рис. 3) визначається 3 виразу

$$
Q_{B}=M_{n p .32 .} \cdot C_{\mu v}\left(T_{b}-T_{a}\right),
$$

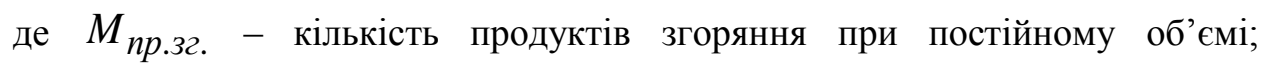

$C_{\mu v}$ - середня мольна теплоємність продуктів згоряння при постійному об'ємі.

Кількість ендотермічної теплоти конверсії $Q_{c}$ визначається 3 (8) та 3 виразу

$$
Q_{c}=M_{n p .32 .} \cdot C_{\mu v}\left(T_{b}-T_{\kappa}\right)
$$

Інакше кажучи ступінь регенерації залежить від температури конверсійного процесу $T_{\kappa}$, зростає 3 iї зменшенням та знаходиться 3 виразу

$$
\eta_{p}=\frac{T_{b}-T_{\kappa}}{T_{b}-T_{a}} .
$$

\section{Підвищення термічного ККД двигуна}

Очевидно, що зазначені вимоги 3 температурного рівня відпрацьованих газів двигуна можуть бути забезпечені не у всіх діапазонах режимів роботи двигунів внутрішнього згоряння. Наприклад, для непрогрітого до робочої температури двигуна ступінь регенерації конверсійного процесу буде знижена. Але потрібно зауважити, що час роботи двигуна на режимі прогрівання $\epsilon$ досить не тривалим. Крім того, слід відмітити, що реалізувати конверсію альтернативних палив при нижчих робочих температурах дозволяють сучасні каталізатори. Наприклад, для метанолу це $300-400{ }^{\circ} \mathrm{C}$ [21], визначаючи тим самим мінімально можливий температурний режим відпрацьованих газів в двигунах внутрішнього згоряння, при якому ще можна здійснити організацію конверсійного процесу. Тому на сьогоднішній день можна говорити про можливість майже постійного конверсійного процесу в двигунах внутрішнього згоряння за рахунок регенерації теплоти відпрацьованих газів.

Для аналізу можливості підвищення ефективності використання хімічної енергії палива порівняємо можливості його енергоперетворення в двох енергетично подібних двигунах внутрішнього згоряння. Перший працює за звичайною схемою, другий - 3 використанням термохімічних регенерації в дві стадії. Необхідний тепловий режим конверсії палива забезпечується за рахунок підведення теплоти відпрацьованих газів. 
Перший двигун працює наступним чином. Початкове паливо при параметрах навколишнього середовища надходить в двигун, де згоряє 3 виділенням теплоти $Q_{n}=$ Hu. Ця теплота передається робочому тілу. Для спрощення аналізу будемо вважати, що

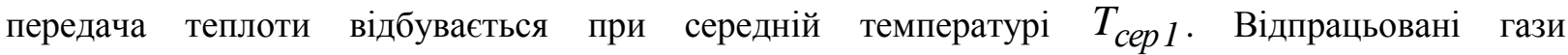
після скоєння циклу відводяться в атмосферу. Для спрощення аналізу будемо вважати, що відведення теплоти відбувається при середній температурі $T_{c e p 2}$. Тоді вироблена двигуном робота може бути визначена наступним чином

$$
L_{\mathcal{M}}=H u . м \frac{T_{\text {cep } 1}-T_{\text {cep } 2}}{T_{\text {cep } 1}} .
$$

При цьому ефективність використання хімічної енергії палива дорівнює

$$
\eta=\frac{L_{M}}{H u . M}=\frac{T_{c e p 1}-T_{c e p ~}}{T_{\text {cep } 1}}
$$

Залежність (13) визначає ККД теплосилової установки, який дорівнює відношенню кількості енергії, перетвореної в роботу, до всієї енергії, що надійшла в теплосилову установку. При цьому ККД даної ідеалізованої установки збігається 3 термічним ККД циклу. Це свідчить про те, що в двигуні без термохимической регенерації ефективність використання енергії палива цілком залежить від перетворення теплоти в роботу i не може перевищити ефективність перетворення останньої.

Другий двигун працює 3 термохімічною регенерацією теплоти відпрацьованих газів.

На відміну від першого двигуна паливо в камеру згоряння надходить не відразу, а попередньо проходить стадію термохімічної переробки в термохімічному реакторі. У ньому під дією теплоти, що надходить при середній нижній температурі $T_{c e p 2}$, відбувається термохімічне перетворення вихідного палива в конвертоване, яке і подається на спалювання в камеру згоряння двигуна. Якщо прийняти, що теплообмін в цьому двигуні здійснюється аналогічно першому варіанту, то робоче тіло другого двигуна 3 термохімічним реактором має отримати теплоту також при середній температурі $T_{c e p ~}$.

Тоді в цьому випадку сприйнята робочим тілом теплота Ни.n.м перевищує теплоту згоряння Ни.м вихідного палива на величину Ни.к, яка була поглинена при термохімічної перетворенні вихідного палива в термохімічному реакторі та відповідно дорівнює

$$
\text { Hu.n.м }=H u . м+H u . \kappa
$$

Будемо вважати, що двигун 3 термохімічним реактором перетворює сприйняту робочим тілом теплоту 3 тією ж ефективністю, що $\mathrm{i}$ двигун без термохімічного реактору, тобто термічний ККД обох установок однаковий. Тоді робота, яку може зробити двигун 3 термохімічним реактором буде дорівнює

$$
L_{n . M}=(H u . м+H u . \kappa) \frac{T_{c e p 1}-T_{\text {cep } 2}}{T_{\text {cep } 1}} .
$$

Тоді ефективність використання енергії палива в двигуні, що містить вузол термохимической регенерації теплоти буде визначатись 3 виразу

$$
\eta_{n . M}=\left(\frac{H u . M+H u . \kappa}{H u . M}\right)\left(\frac{T_{\text {сер } 1}-T_{\text {сер } 2}}{T_{\text {cep } 1}}\right)=\frac{H u . n . M}{H u . M}\left(\frac{T_{\text {cер } 1}-T_{\text {cep } 2}}{T_{\text {cep } 1}}\right) .
$$


Проаналізуємо ефективність використання енергії палива в двигуні, що містить вузол термохимической регенерації та працює на метанолі у порівнянні зі звичайним двигуном. Приймаємо середню верхню температуру циклу $T_{c e p l}=2000 \mathrm{~K}$, а середню нижню - $T_{\text {cep } 2}=1200$ К. Тоді згідно залежності (13) маємо термічний ККД звичайного двигуна $\eta_{M}=40 \%$. Як було показано вище, теплота згоряння метанолу Ни.м складає 19670 кДж / кг. Теплота згоряння газоподібних продуктів конверсії метанолу Ни.n.м складає 23870 кДж / кг. Тоді для двигуна 3 термохімічною регенерацією його термічний ККД $\eta_{n . м}$ буде перевищувати термічний ККД $\eta_{\mathcal{M}}$ першого двигуна в $(23870 / 19670)=1,214$ рази, тобто для двигуна 3 термохімічною регенерацією його термічний ККД буде рівним $\eta_{n . м}=48,5 \%$.

3 наведеного аналізу випливає, що незворотні зовнішні втрати перетворення хімічної енергії палива в теплоту в разі використання методу термохимической регенерації теплоти відпрацьованих газів завжди менше відповідних втрат при безпосередньому спалюванні палива без його попередньої термохімічної переробки. Причому зменшення незворотних втрат адекватно енергії, яку необхідно витрачати на компенсацію сумарного теплового ендотермічного ефекту реакцій конверсії вихідного палива. Теоретичні основи подібних систем живлення двигунів внутрішнього згоряння в сучасній дослідницькій практиці залишаються маловивченими. Однак вони представляють суттєвий інтерес 3 точки зору оцінки потенційних можливостей застосування двигунів 3

термохімічною регенерацією в складі систем живлення i підвищення ефективності використання енергії альтернативних видів палива, зокрема для існуючих дизельних двигунів, які будуть переобладнані на газові.

Реалізація термохімічного способу утилізації теплоти для умов робочого циклу двигунів внутрішнього згоряння 3 іскровим запалюванням можлива, якщо в якості вихідного палива використовувати вуглеводневі сполуки 3 відносно низькою температурою реакцій конверсії (спирти, ефіри та аналогічні сполуки). Газоподібні продукти конверсії можуть бути застосовані як основне паливо для живлення газового двигуна. При цьому важливим $є$ можливість реалізації цього способу в складі систем живлення дизельних двигунів, які конвертуються на газові палива. Проаналізуємо умови для досягнення максимально можливої мірі регенерації. Умови досягнення максимально можливій мірі регенерації виконуються, коли ендотермічний ефект реакції конверсії відповідає підводу еквівалентної кількості теплоти в реакційний простір від зовнішнього джерела - гріючого теплоносія, в ролі якого виступають теплота відпрацьованих газів двигуна та може виступати теплота системи охолодження.

В реальних умовах конверсійного процесу у випускний системі двигуна внутрішнього згоряння теплоносій (відпрацьовані гази та охолоджуюча рідина) повинен мати у своєму розпорядженні потенційно більш високий рівень енергії, яка використовується не тільки для компенсації ендотермічного ефекту реакції конверсії, а й для організації iï допоміжних циклів. Енергія необхідна для попереднього нагріву вихідного палива до температури кипіння, його випаровування, підвищення температури парів до температури дисоціації, компенсації теплових втрат в навколишнє середовище через стінки реактора i підвідних трубопроводів. Наприклад, загальні витрати теплової енергії на повністю завершену конверсію 1 кг метанолу досягають 7 МДж [22]. При цьому на компенсацію ендотермічного ефекту реакції конверсії спирту витрачається близько $60 \%$ загальних енергетичних витрат. Значна їх частина (близько $25 \%$ ) витрачається на енергоємний процес пароутворення (теплота випаровування метанолу 1,1 МДж/кг). Тобто максимально можливий ступінь регенерації досягається за умови, коли теплова енергія теплоносія перевищує загальні витрати енергії, що необхідні для конверсійного процесу.

Експериментальні дослідження екологічних показників дизельного двигуна конвертованого для роботи на газоподібних продуктах конвертації метанолу

Метою експериментальних досліджень $є$ застосування продуктів конвертації метанолу

в альтернативних паливних сумішах в існуючих дизельних двигунах для економії нафтового моторного палива та поліпшення їx екологічних показників. Оцінка 
ефективності термохімічного способу утилізації теплоти в умовах робочого циклу дизеля типу Д21А була проведена в лабораторних умовах на моторному стенді (рис. 2).

Схема експериментального стенду на базі дизельного двигуна Д21А1 для дослідження показників його роботи продуктах конверсії метанолу зображена на рис. 3. Двигун експериментального стенду міг працювати в трьох режимах: подача дизельного палива в зрідженій фазі через форсунки; подача продуктів конверсії метанолу через газовий редуктор; подача метанолу в зрідженій фазі через форсунки. Метанол подавався 3 паливного баку за допомогою електричного паливного насосу через регулятор тиску палива. Для компенсації відносно низької теплоти згоряння метанолу та збільшення його подачі регулятор тиску палива забезпечував подачу метанолу під тиском 0,5 МПа.

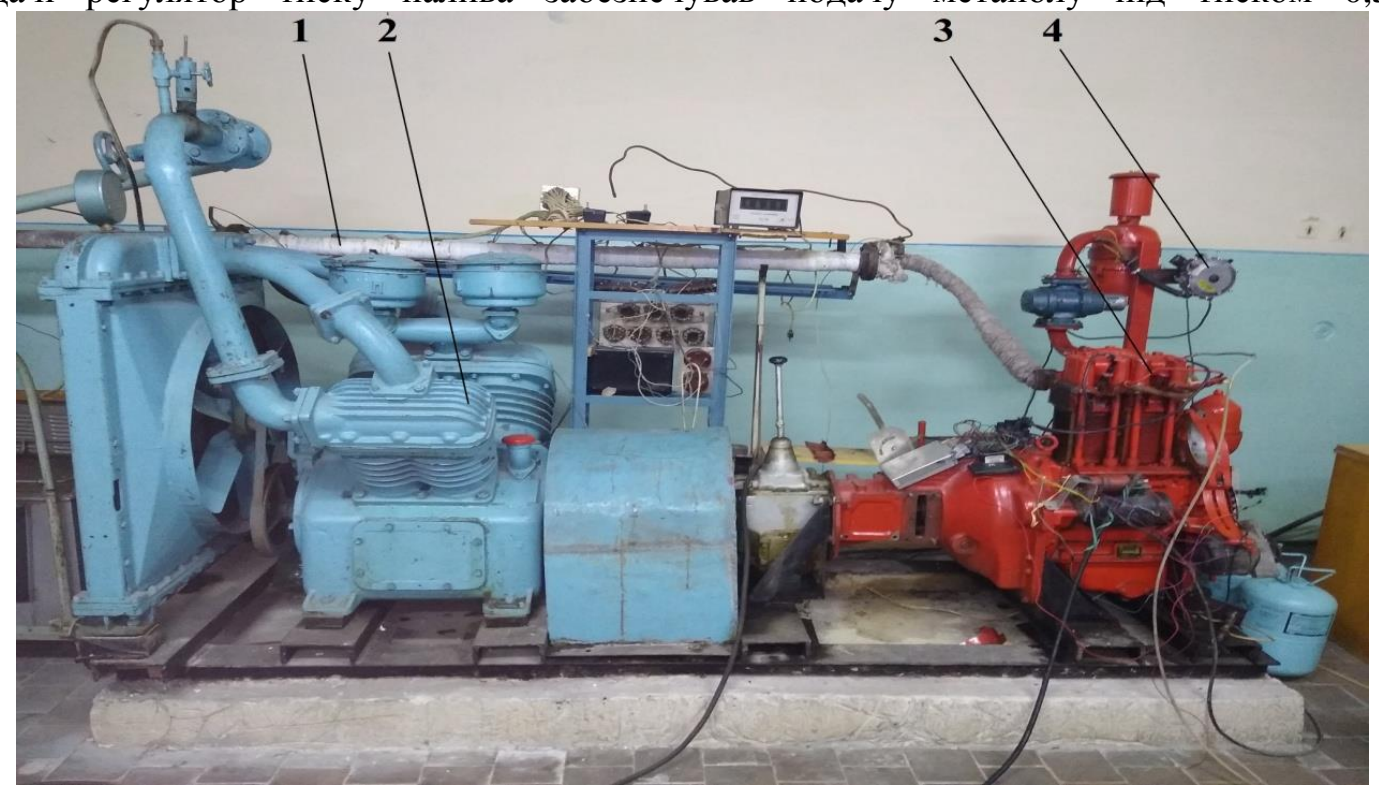

1 - термохімічний реактор; 2 - навантажувальний пристрій двигуна внутрішнього згоряння; 3 - дизельний двигун Д21А1; 4 - газовий редуктор

Рисунок 2 - Зовнішній вигляд експериментального стенду на базі дизельного двигуна Д21A1 для дослідження показників роботи на альтернативних паливних сумішах

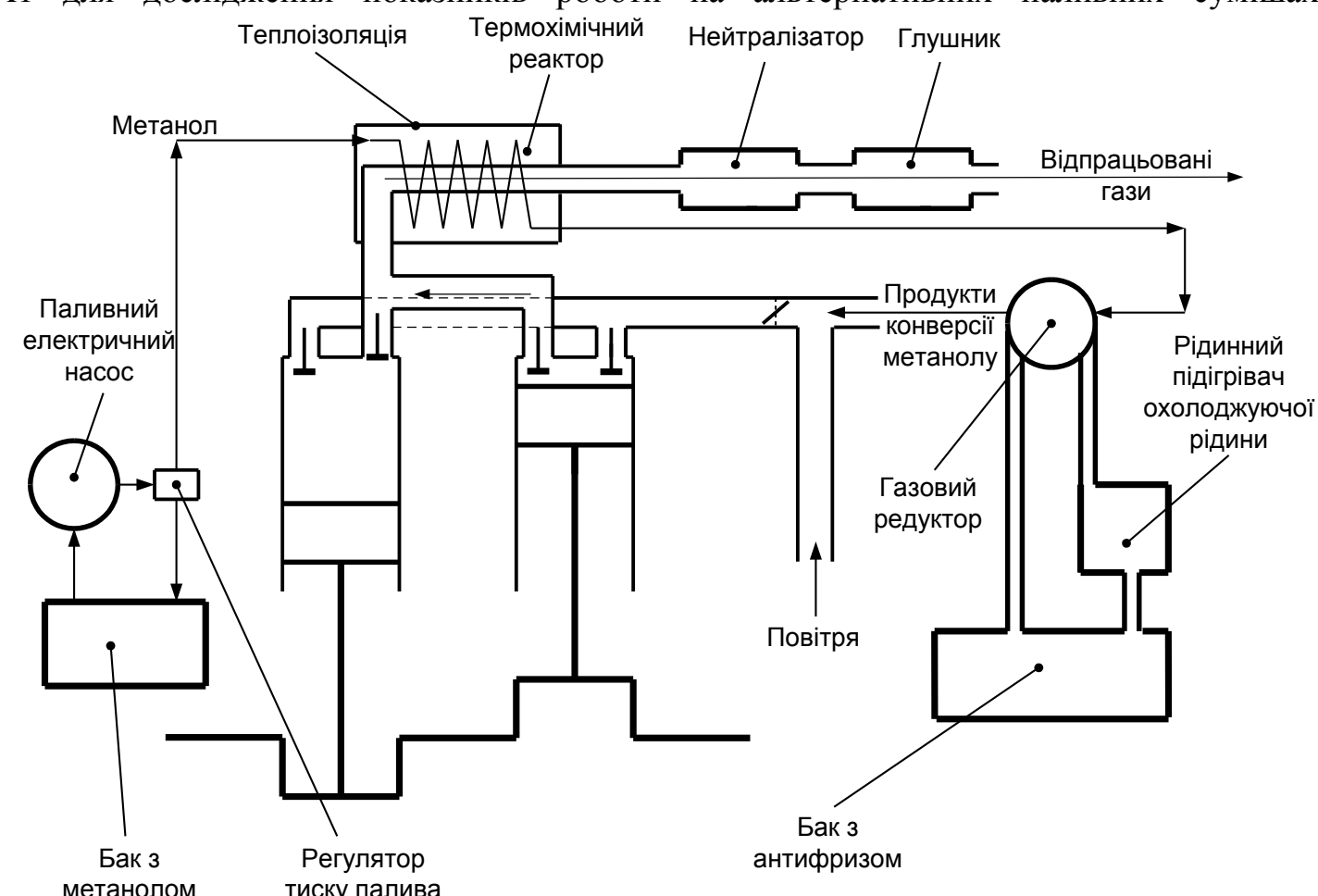

Рисунок 3 - Схема експериментального стенду на базі дизельного двигуна Д21А1 для дослідження показників його роботи продуктах конверсії метанолу 
Для забезпечення регулювання метанольно-повітряної суміші на двигун був змонтований дросельний патрубок 3 дросельною заслінкою. Підігрів метанолу для одержання продуктів конверсії здійснювався від відпрацьованих газів або використовувався рідинний підігрівач охолоджуючої рідини під час пуску холодного двигуна та при його прогріванні. Для забезпечення холодного пуску двигуна в режимі роботи від продуктів конверсії метанолу перед газовим редуктором був змонтований рідинний підігрівач охолоджуючої рідини Webasto Thermo Top C $(5$ kBm). Рідинний підігрівач охолоджуючої рідини відключався при досягненні відпрацьованими газами температури $300{ }^{\circ} \mathrm{C}$. Термокаталітичний реактор конверсії метанолу встановлювався у випускний системі дизеля в безпосередній близькості від випускного колектора.

Паливно-повітряна суміш запалювалась за допомогою електронної системи запалення власної розробки. Розроблена оригінальна електронна система запалення складається 3 блоку управління, який змінює кут випередження запалення в залежності від режиму роботи двигуна, комутатора, модуля запалення, високовольтних дротів та свічок запалення.

Дизельний двигун Д21А1 було переобладнано для роботи на альтернативній газовій суміші. Для цього 3 головок блоку були демонтовані дизельні форсунки, нарізана додаткова різьба в каналах розпилювачів форсунок та встановлені свічки запалення. Дизельний двигун Д21A1 з демонтованими головками блока зображений на рис. 4.

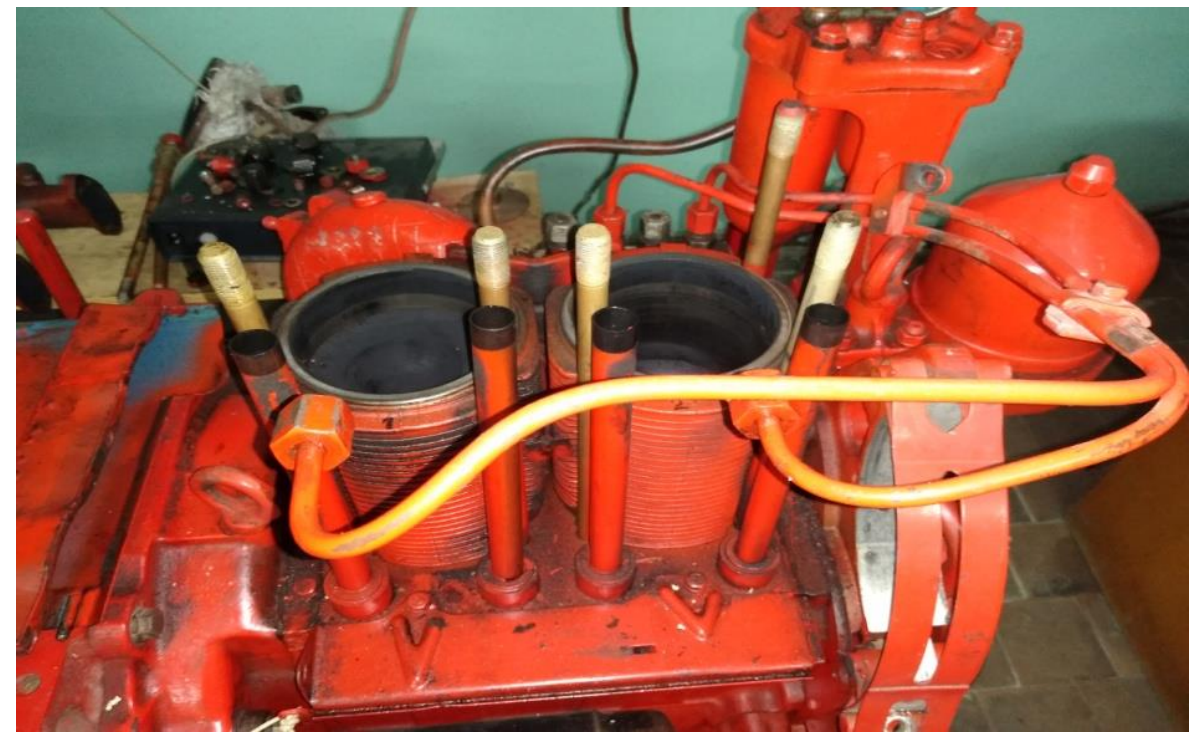

Рисунок 4 - Дизельний двигун Д21А1 3 демонтованими головками блока

Конструкція головок блоку двигуна перероблена таким чином, щоб замість свічок запалення можна було легко вкрутити назад дизельні форсунки. Конвертований таким чином експериментальний двигун дозволяє за час до 10 хвилин переходити на дизельне паливо або метанольне паливо міняючи місцями дизельні форсунки та свічки запалення. Переобладнані 3 дизельного палива на газове головки блока двигуна Д21A1 показані на рис. 5.

Метою експериментальних досліджень було порівняння основних екологічних характеристик переобладнаного дизельного двигуна при його роботі на дизельному паливі та продуктах конвертації метанолу. Для оцінки енергозберігаючого ефекту були проведені експериментальні дослідження на моторному стенді двигуна Д21А1. 


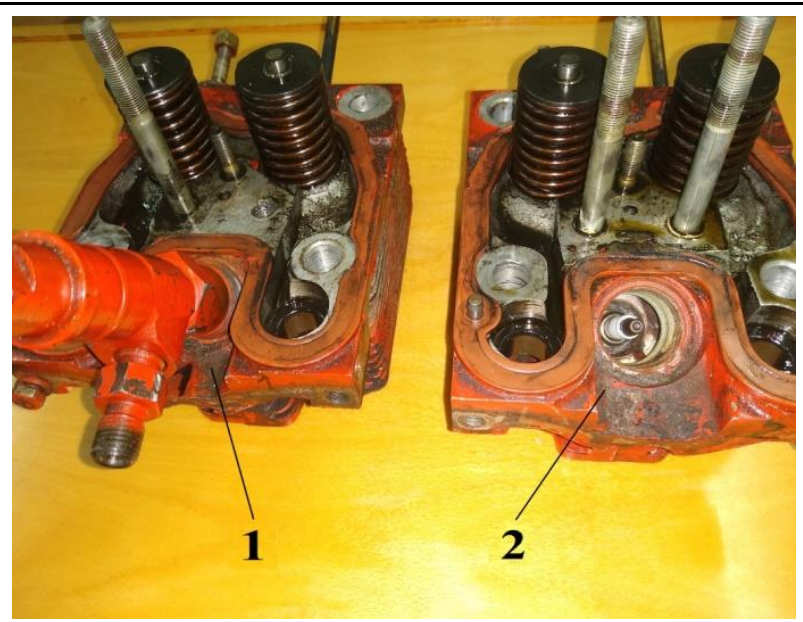

a

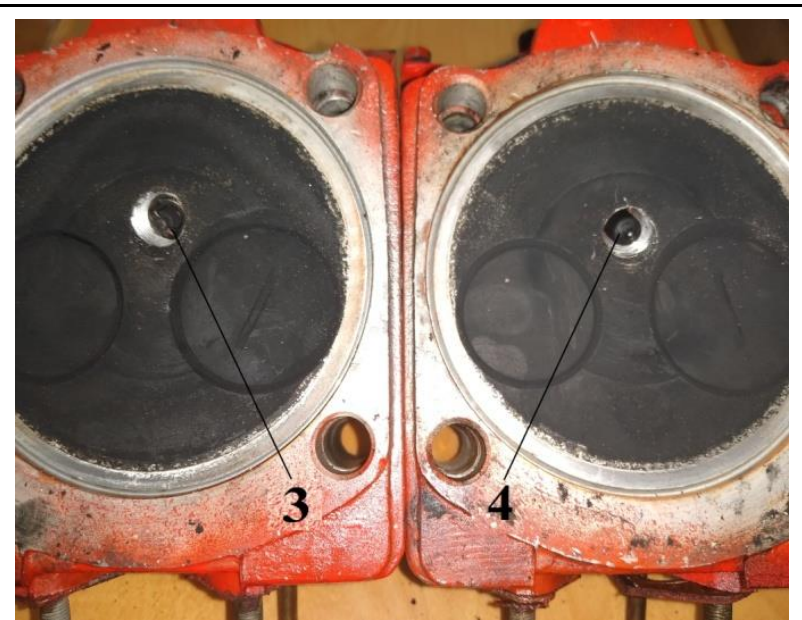

б

1 - головка блока до переобладнання 3 встановленою дизельною форсункою;

2 - головка блока після переобладнання 3 демонтованою форсункою та встановленою свічкою запалення; 3 - свічка запалення; 4 - дизельна форсунка

Рисунок 5 - Переобладнані 3 дизельного палива на газове паливо головки блока. Вигляд 3 боку клапанів ГРМ (а) та камери згорання (б)

Аналізуючи зміни вмісту токсичних компонентів у відпрацьованих газах при переході 3 дизельного палива на продукти конвертації метанолу можна відмітити наступне. Відбувається істотне зниження вмісту оксидів азоту у всьому діапазоні частоти обертання колінчастого валу (рис. 6). Так, при $\mathrm{n}=800 \mathrm{xв}^{-1}$ вміст оксидів азоту знизився $31135 \mathrm{ppm}$ при роботі двигуна на дизельному паливі до $460 \mathrm{ppm}$ при роботі двигуна на продуктах конвертації метанолу. Тобто зниження вмісту оксидів азоту склало 59,6 \%. При $\mathrm{n}=1800 \mathrm{xв}^{-1}$ вміст оксидів азоту знизився $3825 \mathrm{ppm}$ при роботі двигуна на дизельному паливі до $305 \mathrm{ppm}$ при роботі двигуна на продуктах конвертації метанолу. Тобто зниження вмісту оксидів азоту склало $53,0 \%$. Зниження вмісту оксидів азоту при роботі двигуна на дизельному паливі у порівнянні 3 роботою двигуна на продуктах конвертації метанолу пояснюється нижчими швидкостями тепловідділення та меншим зростання тиску згоряння в двигуні.

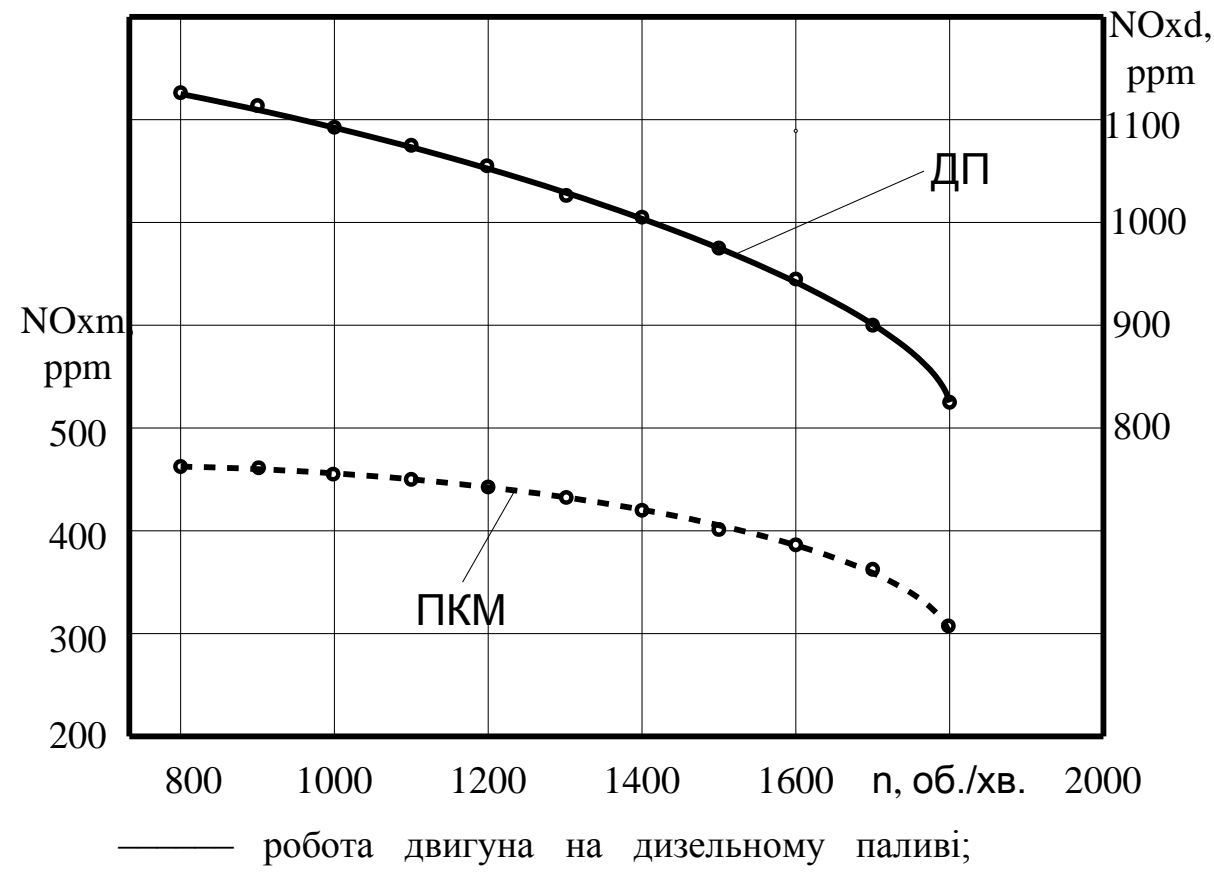

........ робота двигуна на продуктах конвертації метанолу;

Рисунок 6 - Експериментальні залежності вмісту оксидів азоту у відпрацьованих газах від частоти обертання колінчастого вала двигуна $n$ за різного моторного палива 
Відбувається суттєве зниження вмісту оксиду вуглецю у всьому діапазоні частоти обертання колінчастого валу (рис. 7). Так, при $\mathrm{n}=800 \mathrm{xB}^{-1}$ вміст оксиду вуглецю знизився 3 0,225 \% при роботі двигуна на дизельному паливі до $0,150 \%$ при роботі двигуна на продуктах конвертації метанолу. При $\mathrm{n}=1800 \mathrm{xв}^{-1}$ вміст оксиду вуглецю знизився 3 0,085 \% при роботі двигуна на дизельному паливі до 0,072 \% при роботі двигуна на продуктах конвертації метанолу. Тобто зниження вмісту оксиду вуглецю відбувається в межах 62,2-52,0 \%.

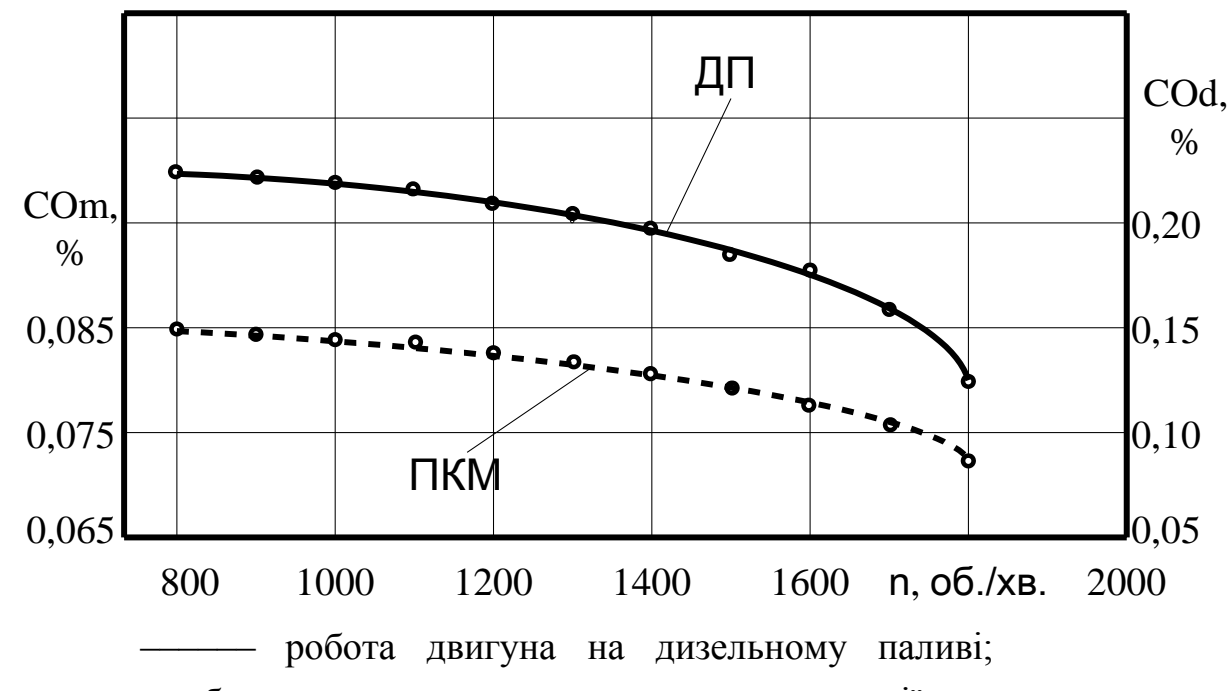

........ робота двигуна на продуктах конвертації метанолу;

Рисунок 7 - Експериментальні залежності вмісту оксиду вуглецю у відпрацьованих газах від частоти обертання колінчастого вала двигуна $n$ за різного моторного палива

Вміст вуглеводнів дещо підвищується у всьому діапазоні частоти обертання колінчастого валу (рис. 8). Так, при $\mathrm{n}=800 \mathrm{xв}^{-1}$ вміст вуглеводнів змінюється 3 $0,042 \%$ при роботі двигуна на дизельному паливі до $0,031 \%$ при роботі двигуна на продуктах конвертації метанолу. Тобто зниження вмісту вуглеводнів склало 26,2 \%. При $\mathrm{n}=1800$ хв $^{-1}$ вміст вуглеводнів зростає 3 0,077 \% при роботі двигуна на дизельному паливі до 0,155 \% при роботі двигуна на продуктах конвертації метанолу. Тобто підвищення вмісту вуглеводнів склало 2,01 рази.

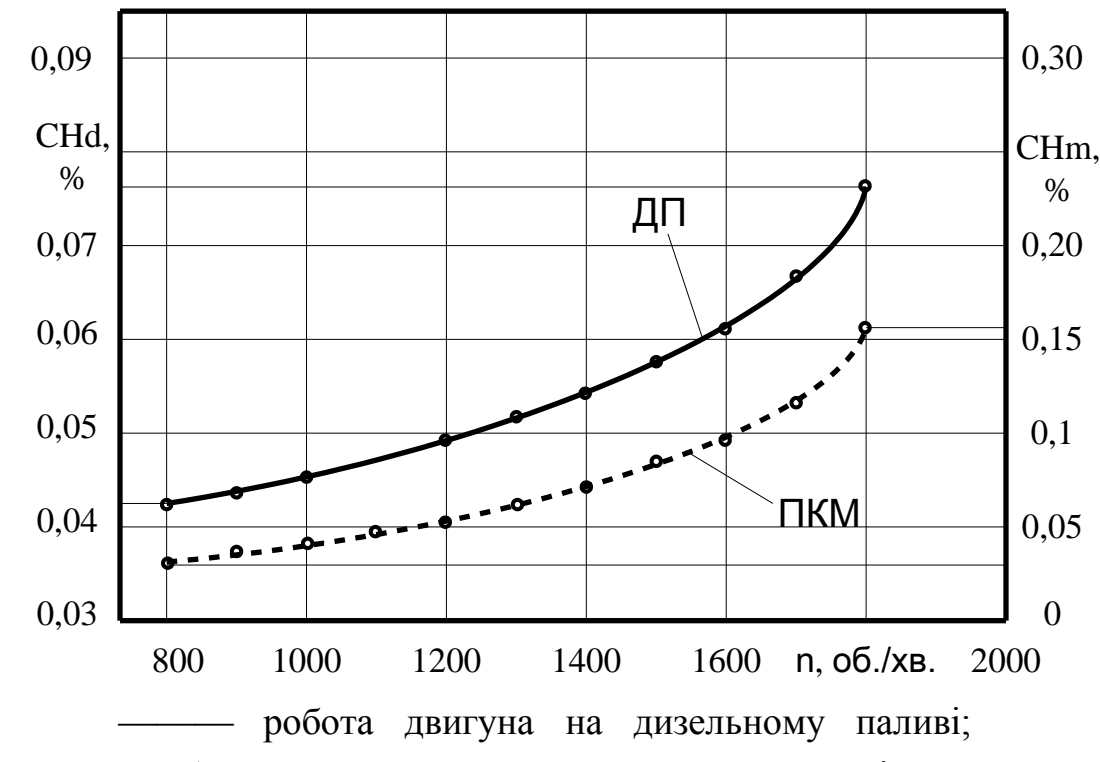

Рисунок 8 - Експериментальні залежності вмісту вуглеводнів у відпрацьованих газах від частоти обертання колінчастого вала двигуна $n$ за різного моторного палива 
Було також проведене порівняння роботи двигуна на зрідженому метанолі та на продуктах конверсії метанолу. В середньому, під час експериментальних досліджень при роботі на продуктах конверсії метанолу, у порівнянні 3 роботою двигуна на зрідженому метанолі, реєструвалось зниження витрати палива в діапазоні $10-14$ \% у залежності від частоти обертання колінчастого валу та навантаження на двигун.

Для виявлення частки участі кожного фактора в підвищенні економічності двигуна проведено його випробування 3 використанням реактора конверсії метанолу 3 автономним електричним підігрівачем, тобто без використання (регенерації) теплової енергії відпрацьованих газів. Встановлено, що енергозбереження для даного дизеля за рахунок термохімічного способу утилізації теплоти становило 6-8 \%, а за рахунок вдосконалення робочого процесу - близько 4-6\%.

Для виявлення факторів поліпшення паливної економічності досліджуваного двигуна було проведено додаткове експериментальне дослідження. На першій стадії випробувань 3 використанням газобалонної системи живлення в циліндри двигуна подавали синтез-газ, який має компонентний склад (об'ємні частки), аналогічний складу продуктів конверсії метанолу: $33 \%$ CO та $67 \%$ $H_{2}$.

Очевидно, що в даному випадку ефект утилізації теплової енергії відпрацьованих газів не проявляється. На другій стадії випробувань двигун працював спільно 3 термохімічним реактором. Утилізована енергія відпрацьованих газів, перетворена в новий вид газоподібного палива (продукти конверсії метанолу) 3 більш високими енергетичними показниками, використовувалася для здійснення додаткової корисної роботи. Тобто двигун працював за схемою регенеративного циклу.

3 урахуванням того, що в обох випадках паливо мало один i той же компонентний склад, його показники згоряння, a значить $\mathrm{i}$ характер впливу на кінетичні параметри робочого циклу були ідентичними. Отже, підвищення економічності двигуна, що спостерігалось в експериментальних дослідженнях, однозначно відповідало ефекту термохимической регенерації енергії відпрацьованих газів.

\section{ОБГОВОРЕННЯ РЕЗУЛЬТАТІВ ДОСЛІДЖЕННЯ}

Проведені дослідження показали, що переведення дизельних двигунів на роботу 3 використанням продуктів конверсії метанолу $\epsilon$ досить вигідним. Зниження витрати палива супроводжується поліпшенням екологічних якостей дизеля, що працює спільно 3 термохімічним реактором конверсії метанолу. Зокрема, у залежності від частоти обертання колінчастого валу та навантаження на двигун утворення оксидів азоту у відпрацьованих газах знижувалося на 53-60 \%, оксиду вуглецю відбувалось в межах 52$62 \%$.

\section{ВИСНОВКИ}

Дослідженнями встановлено, що на навантажувальних режимах, коли температура відпрацьованих газів на вході в реактор перевищує $400{ }^{\circ} \mathrm{C}$, продуктивність реактора, в тому числі i за цільовим компонентом $H_{2}$, досягає свого найвищого рівня, помітно підвищуючи ефективність робочого циклу. Застосування розглянутого способу утилізації енергії випускних газів в транспортних двигунах представляється досить перспективним. Завдяки технічній простоті його реалізація не вимагає великих фінансових вкладень та кардинального переобладнання існуючого виробництва двигунів.

В якості базового двигуна може бути використана будь-яка серійна модель дизельних двигунів. Це стосується як тих двигунів, що знаходяться в експлуатації, так i нових двигунів. Основний елемент конверсійної системи - термохімічний реактор являє собою найпростішу конструкцію теплообмінного апарату, масові та габаритні характеристики якого в обсязі звичайного глушника забезпечують зручність його установки у випускний системі двигуна.

Важливим стимулом подальшого розвитку подібних систем $\epsilon$ те, що вони обумовлюють можливість сукупного вдосконалення характеристик транспортного засобу за комплексом показників. Їх реалізація на транспортних засобах дозволяе, зокрема, утилізувати відхідну теплову енергію, удосконалювати процеси згоряння, покращувати екологічні якості транспортних засобів, забезпечуючи при цьому можливість заміни традиційного нафтового палива альтернативним енергоносієм 3 поновлюваних, в тому 
() Криштопа С.І., Криштопа Л.І., Микитій I.М., Гнип М.М., Козак Ф.В. 2021

числі біологічних джерел, сприяючи таким чином вирішенню глобальної проблеми ресурсозбереження.

\section{ПЕРЕЛІК ДЖЕРЕЛ ПОСИЛАННЯ}

1. Panchuk, M., Kryshtopa, S., Sladkowski, A., Panchuk, A., Mandryk, I. Efficiency of production of motor biofuels for water and land transport. Nase More 2019, 66 (3), 6-12.

2. Panchuk, M.; Kryshtopa, S.; Sładkowski, A.; Panchuk, A. Environmental Aspects of the Production and Use of Biofuels in Transport. Lecture Notes in Networks and Systems: Book Chapter 2020, 124, 115-168.

3. Vershina G., Bystrenkov O. Influence of Diesel Fuel Ignition Portion Value on Working Process Parameters of Gas-Diesel Engine. Science \& Technique. 2019, 18(5), 395-400.

4. Boretti A. Advantages and Disadvantages of Diesel Single and Dual-Fuel Engines. Front. Mech. Eng. 2019, 5, 64.

5. Panchuk, M., Kryshtopa, S., Panchuk, A., Mandryk, I., Sladkowski, A. Perspectives for developing and using the torrefaction technology in Ukraine. International Journal of Energy for a Clean Environment 2019, 20(2), 113-134.

6. Zhanga K., Xin Q., Mu Z., Niu Z., Wanga Z. Numerical simulation of diesel combustion based on n-heptane and toluene. Propulsion and Power Research 2019, 8, 2, 121-127.

7. Firmansyaha, A. Aziz A. Investigation of Auto-ignition of Several Single Fuels. MATEC Web of Conferences. 4th International Conference on Production, Energy and Reliability 2014, 13, 02013

8. Kryshtopa, S., Melnyk, V., Dolishnii, B., Zakhara, I., Voitsekhivska, T. Improvement of the model of forecasting heavy metals of exhaust gases of motor vehicles in the soil. Eastern-European Journal of Enterprise Technologies 2019, 4 (10-100), 1-8.

9. Kryshtopa, S., Kryshtopa, L., Melnyk, V., Prunko, I., Demianchuk, Y. Experimental research on diesel engine working on a mixture of diesel fuel and fusel oils. Transport Problems 2017, 12 (2), 53-63.

10.Abbasi S., Bahrami H., Ghobadian B., Kiani M., Kiani D. Energy Analysis of a Diesel Engine Using Diesel and Biodiesel from Waste Cooking Oil. JOURNAL OF AGRICULTURAL MACHINERY. 2018, $8,1,149-157$.

11.Afanas'ev A., Tret'yakov A. Simulation of diesel engine energy conversion processes. Journal of Mining Institute. 2016. 222. 839-852.

12.Abbondanza M., Cavina N., Corti E., Moro D., Ponti F., Ravaglioli V. Development of a Combustion Delay Model in the Control of Innovative Combustions. E3S WEB OF CONFERENCES. 2020, $197,6013$.

13.Bildirici, M., Gökmenoğlu, S. Environmental pollution, hydropower energy consumption and economic growth: Evidence from G7 countries. Renewable and Sustainable Energy Reviews, 2016, 75, 6885.

14.Bahman N., Sina F., Shahaboddin S., Kwok-wing C., Timon R. Application of ANNs, ANFIS and RSM to estimating and optimizing the parameters that affect the yield and cost of biodiesel production. Engineering Applications of Computational Fluid Mechanics 2018. 12, 1, 611-624.

15.Zhang, Z. Experimental Investigation on Regulated and Unregulated Emissions of a Diesel/ Methanol Compound Combustion Engine with and without Diesel Oxidation Catalyst. Science of the Total Environment, 2010, 408, 4, 865-872.

16.Li, Y. Numerical Study on the Combustion and Emission Characteristics of a Methanol/Diesel Reactivity Controlled Compression Ignition (RCCI) Engine. Applied Energy, 2013, 106, 2, 184-197.

17.Liu, Z. Economic Analysis of Methanol Production from Coal/Biomass Upgrading, Energy Sources Part B-Economics Planning and Policy, 2018, 13, 1, 66-71.

18.He L., Fu Y., Lidstrom M. Quantifying Methane and Methanol Metabolism of "Methylotuvimicrobium buryatense" 5GB1C under Substrate Limitation. MSYSTEMS 2019, 4, 6, 748-19.

19.Mäyrä O., Leiviskä K. Modeling in methanol synthesis, Methanol, Elsevier 2018, 475-492.

20. Yakovlieva A., Boichenko S. Energy Efficient Renewable Feedstock for Alternative Motor Fuels Production: Solutions for Ukraine. Studies in Systems, Decision and Control 2020. 298, 247-259.

21.Alarifi A., Alsobhi S., Elkamel A., Croiset E. Multiobjective optimization of methanol synthesis loop from synthesis gas via a multibed adiabatic reactor with additional interstage CO2 quenching, Energy Fuels 2015, 29, 2, 530-537.

22.Dalena F., Senatore A., Marino A., Gordano A., Basile M., Basile A. Methanol production and applications: An overview, Methanol, Elsevier, 2018, 3-28. 
S. Kryshtopa, L. Kryshtopa, I. Mykytii, M. Hnyp, F. Kozak. Improving the environmental parameters of diesel engines when they are transferred to methanol conversion products

The article aims to solve the problem of converting existing automobile diesel engines to gas fuels, which are a cheaper and more environmentally friendly alternative to diesel fuel. Method of increasing energy of alternative fuels was improved. Chemical essence of fuel energy increase is considered on the basis of scientific provisions of thermodynamics. As a starting point for the conversion process, an alternative methanol fuel was selected, taking into account its cost, environmental friendliness and temperature conditions. The calculations showed that thermal effect from combustion of the converted mixture exceeds the effect from combustion of the same amount of non-convertible methanol. Fuel energy increased due to thermochemical regeneration of exhaust gas heat. An experimental setup has been created to study the operation of a converted diesel engine at methanol conversion points. Experimental studies of environmental performance of a diesel engine, which was converted to work at methanol conversion points. Experimental studies have shown that the conversion of diesel engines to work using methanol conversion points is technically justified. Reduction in fuel consumption was accompanied by an improvement in the environmental performance of the diesel engine, which works in conjunction with a thermochemical methanol conversion reactor. Depending on the speed of the crankshaft and the load on the engine, the formation of nitrogen oxides in the exhaust gases decreased by 53-60\%, carbon monoxide occurred in the range of $52-62 \%$. Given that the price of methanol is up to $20 \%$ of the cost of diesel fuel, the conversion of automotive diesel engines to work using methanol conversion points is very profitable.

Keywords: diesel engine; alternative fuel; methyl alcohol; heat utilization; exhaust gases; nitrogen oxides; hydrocarbons.

КРИШТОПА Святослав Ігорович, доктор технічних наук, професор, завкафедрою автомобільного транспорту, Івано-Франківський національний технічний університет нафти і газу,

E-mail: auto.ifntung@ukr.net, ORCID: http://orcid.org/0000-0001-7899-8817.

КРИШТОПА Людмила Іванівна, кандидат технічних наук, доцент, доцент кафедри автомобільного транспорту, Івано-Франківський національний технічний університет нафти і газу, Еmail: 1.i.kryshtopa@ mail.ru, ORCID: http://orcid.org/0000-0002-5274-0217

МИКИТІЙ Іван Михайлович, аспірант, кафедра автомобільного транспорту, Івано-Франківський національний технічний університет нафти і газу, E-mail: 7ivan1@i.ua, ORCID: https://orcid.org/00000002-8925-6349

ГНИП Марія Михайлівна, доктор філософії, асистент кафедри автомобільного транспорту, Івано-Франківський національний технічний університет нафти і газу, E-mail: marichka_gnip@ukr.net, ORCID: http://orcid.org/0000-0003-3662-0941

КОЗАК Федір Васильович, кандидат технічних наук, професор, професор кафедри автомобільного транспорту, Івано-Франківський національний технічний університет нафти і газу,

E-mail: auto.ifntung@ukr.net, ORCID: http://orcid.org/0000-0002-9147-883X

Sviatoslav KRYSHTOPA, Doctor of Technical Sciences, Professor, Head of Department of Automobile Transport, Ivano-Frankivsk National Technical University of Oil and Gas

E-mail: auto.ifntung@ukr.net, ORCID: http://orcid.org/0000-0001-7899-8817

Liudmyla KRYSHTOPA, PhD, Associate Professor, Department of Automobile Transport, IvanoFrankivsk National Technical University of Oil and Gas, E-mail: 1.i.kryshtopa@mail.ru, ORCID: http://orcid.org/0000-0002-5274-0217

Ivan MYKYTII, Postgraduate student, Department of Automobile Transport, Ivano-Frankivsk National Technical University of Oil and Gas, E-mail: 7ivan1@i.ua, ORCID: https://orcid.org/0000-0002-8925-6349

Mariia HNYP, Postgraduate student, Department of Automobile Transport, Ivano-Frankivsk National Technical University of Oil and Gas, E-mail: marichka_gnip@ukr.net, ORCID: http://orcid.org/0000-0003$\underline{3662-0941}$

Fedir KOZAK, PhD, Professor, Department of Automobile Transport, Ivano-Frankivsk National Technical University of Oil and Gas

E-mail: auto.ifntung@ukr.net, ORCID: http://orcid.org/0000-0002-9147-883X

DOI 10.36910/automash.v1i16.512 